\title{
Vital Pulp Therapy in Aesthetic Zone-Identifying the Biomaterial That Reduces the Risk of Tooth Discolouration
}

\author{
Joanna Metlerska ${ }^{1, *}$, Irini Fagogeni ${ }^{2}$, Marcin Metlerski ${ }^{3}$ and Alicja Nowicka ${ }^{1}$ (D) \\ 1 Department of Conservative Dentistry and Endodontics, Pomeranian Medical University in Szczecin, \\ 70-111 Szczecin, Poland; nowicka6@gmail.com \\ 2 Doctoral Studies of the Faculty of Dentistry, Pomeranian Medical University in Szczecin, \\ 70-111 Szczecin, Poland; irini.fagogeni@gmail.com \\ 3 Department of Oral Surgery, Pomeranian Medical University in Szczecin, 70-111 Szczecin, Poland; \\ m.metlerski@gmail.com \\ * Correspondence: joanna.metlerska@pum.edu.pl; Tel.: +48-91-466-16-48
}

check for updates

Citation: Metlerska, J.; Fagogeni, I.; Metlerski, M.; Nowicka, A. Vital Pulp Therapy in Aesthetic

Zone-Identifying the Biomaterial

That Reduces the Risk of Tooth Discolouration. Materials 2021, 14, 6026. https://doi.org/10.3390/ ma14206026

Academic Editors: Paolo Cappare and Gherlone Felice Enrico

Received: 15 August 2021

Accepted: 8 October 2021

Published: 13 October 2021

Publisher's Note: MDPI stays neutral with regard to jurisdictional claims in published maps and institutional affiliations.

Copyright: (c) 2021 by the authors. Licensee MDPI, Basel, Switzerland. This article is an open access article distributed under the terms and conditions of the Creative Commons Attribution (CC BY) license (https:/ / creativecommons.org/licenses/by/ $4.0 /)$.

\begin{abstract}
Calcium silicate-based cements are biocompatible materials for vital pulp therapy. However, they discolour the tooth tissue, which is important for the aesthetics of the anterior teeth. The aim of this study was to investigate the effect of calcium silicate-based cements on tooth discolouration. The study included 70 extracted bovine incisors. The crown of the tooth was cut off from the root, $2 \mathrm{~mm}$ below the cement-enamel junction. The pulp tissue was removed via a cervical cut with a barbed broach. The teeth were randomly divided into five experimental, one positive, and one negative control groups. The evaluated materials included Biodentine, Ortho MTA, Retro MTA, MTA Plus, MTA Repair HP, and in the positive group, ProRoot MTA. A VITA Easyshade Compact 5.0 spectrophotometer was used before the application, after 1 week, 1 month, 3 months, and 6 months. The significance levels were set at $p<0.05$. All materials significantly changed the teeth colour $(p<0.05)$. However, Ortho MTA, ProRoot MTA, MTA Plus, and Biodentine $(\triangle \mathrm{E}>6)$ caused maximum colour change after 6 months. While the ProRoot MTA, Ortho MTA, and MTA Plus caused grey discolouration, Biodentine darkened the shade of the base colour. Thus, Retro MTA and MTA Repair HP can be safely used in the aesthetic dentition zone. According to these clinical results, the possibility of using Biodentine, due to its lack of gray discoloration, can be considered.
\end{abstract}

Keywords: biomaterials; calcium silicate-based cements; endodontics; staining potential; tooth discolouration

\section{Introduction}

Vital pulp treatment is the latest trend in dentistry. It includes methods such as indirect and direct pulp capping and partial and full pulpotomy [1]. An appropriate application of the above-mentioned procedures not only enables the preservation of vital tissue in permanent teeth but also facilitates apical closure and root development in immature permanent teeth [2]. Clinical symptoms and pain characteristics do not reflect the actual histological state of the pulp. Pain has been reported in several cases with saveable pulps. Moreover, it is difficult to differentiate between reversible and irreversible pulpitis [3]. Therefore, the removal of infected and severely inflamed tissues and dressing the pulp with a biological material would possibly facilitate the conservation of the remaining healthy pulp. This allows the tooth to return to a functional and healthy status. Thus, vital pulp therapies are recommended in dentistry [4].

Indirect pulp treatment is a non-invasive VPT that involves the removal of only the necrotic, infected, softened, humid, and demineralized dentine layer. This procedure leaves the deepest layer of the dentine intact over the pulp tissue. It is followed by the placement of a biocompatible liner and hermetic restoration to provide a seal against microleakage [5]. In contrast, direct pulp capping involves the placement of a material 
directly on a traumatically, cariously or mechanically exposed vital pulp [6]. Pulpotomy comprises the cutting-off of the infected pulp and the capping of the healthy part with biocompatible materials [7,8]. Pulpotomy using calcium silicate-based cements (CSCs) has been applied to treat deep carious lesions with exposed pulps in permanent teeth. The use of pulpotomy has also been extended to permanent mature teeth with symptomatic irreversible pulpitis. Predictably, those teeth can also be treated by the removal of the affected and inflamed tissue, resulting in maintained periapical health and vitality of the remaining pulp [1].

Regenerative endodontic procedures (REPs) are increasingly used and are still being improved. They have been defined as biologically based procedures designed to replace damaged structures, including dentin and root structures, as well as cells of the pulp-dentin complex [9-13]. The purpose of regenerative dentistry is to revitalize pulp that has been damaged by disease, inflammation, or trauma and to replace necrotic pulp tissue with a new pulp-like tissue and preserve tooth function and viability [13]. REPs are based on three principles of bioengineering: mesenchymal stem cells (MSCs), scaffolds, and growth factors [9]. During all regenerative procedures, biological disinfection methods should be used. Such materials, at low concentrations, should be used to stimulate growth cells and avoid damage to cells. Then, the root is filled with a blood clot from the bleeding provoked from apical tissues. The blood clot acts as a scaffold and the growth factors inside recruit stem cells, most likely from periapical papilla. The latest research concerns the use of platelet concentrates that are introduced into the root canal. They contain growth factors, stimulate collagen production, recruit other cells to the site of injury, produce antiinflammatory agents, initiate vascular ingrowth, and induce cell differentation $[9,10,12]$.

Despite the widespread use of calcium hydroxide for pulp closure [14], it gradually breaks down due to solubility [15]. Moreover, tunnel defects and low mechanical properties in the induced tertiary dentine bridges may result in pulp degeneration [16]. CSCs are alternative and more commonly used biocompatible materials for vital pulp therapy. ProRoot MTA (Dentsply, Tulsa, OK, USA) was one of the first such materials available commercially. It has found application in both VPT in permanent teeth [17], and also in primary teeth pulpotomy, replacing formocresol paste [18]. MTA releases calcium ions and causes an alkaline $\mathrm{pH}$, which reaches 12.5 on setting, exerting an antibacterial effect. It releases calcium ions a few days after the hydration and solidification of the material. These ions eventually diffuse through dentine defects in the root canals filled with MTA. Their concentrations are generally limited in time. A contact between the calcium ions (released by the MTA) and tissue fluid leads to the production of hydroxyapatite $[19,20]$. Furthermore, thickening of the MTA in the presence of moisture occurs due to its hydrophilic properties. A combination of the powder with water produces a colloidal and basic gel, which hardens into a fluid-impermeable barrier. This biocompatible material does not cause an inflammatory reaction. In addition, it has no cytotoxic or genotoxic properties [21]. Nonetheless, the disadvantages of MTA include a low flowability, handling difficulties and long setting time [22-24]. One of the significant disadvantages is the discolouration of tooth tissues, which is particularly important for VPT in the anterior part of the teeth [25]. Researchers have developed several CSCs with improved properties that are commercially available. Biodentine (Septodont, Saint-Maur-des-Fossés Cedex, France) is a CSC manufactured as a dentine substitute, for applications similar to those advocated for MTA. The composition of Biodentine has been altered by modifying the composition of the powder, adding bond accelerators, and softeners. The material is available in predefined quantities in capsules for use in a triturator. Biodentine is denser and less porous than MTA. Moreover, it has better compressive and flexural strength. The short setting time is another clinical advantage [26]. Ortho MTA and Retro MTA (BioMTA, Seoul, Korea) have been recently introduced for orthograde and retrograde root-canal filling, perforation repair, apex closure of immature roots. The manufacturer claims similar components in Ortho MTA, compared to ProRoot MTA. However, the former contains lower amounts of heavy metal. Moreover, zirconium oxide was used as a radiopacifer in Retro MTA. MTA Plus (compounded by PrevestDenpro, 
Jammu, India for Avalon Biomed Inc., Bradenton, FL, USA) has a prolonged capability to increase the local $\mathrm{pH}$ and release calcium, compared with ProRoot MTA.

These ion-releasing properties are interlinked with solubility, water sorption, porosity, and formation of a calcium phosphate layer. MTA Plus is a convenient alternative to the MTA-like conventional CSCs, low-cost, bioactive tricalcium silicate material [27]. Despite the similarity in composition between the conventional MTA and MTA Repair HP (Angelus, Londrina, PR, Brazil), the former contains a mixing liquid with a plasticizer agent and calcium tungstate as a radiopacifier. According to the manufacturer, the aforementioned formula improves its physical properties related to manipulation. Moreover, MTA Repair $\mathrm{HP}$ had an extended alkalinising and calcium releasing activity, which in turn favours calcium phosphate nucleation. The addition of the plasticizer in the cement might increase its porosity and solubility [28].

The aim of this study was to investigate the effect of calcium silicate-based cements on the discolouration of tooth tissues. The null hypothesis assumes that CSCs do discolor tooth tissues.

\section{Materials and Methods}

\subsection{Sample Preparation}

Ethical approval was sought and gained by the Local Ethics Committee of Pomeranian Medical University, Szczecin, Poland (approval number KB-0012/80/16). Seventy freshly extracted mandibular bovine incisors (2-4 year-old cows) were used in the study. Specimens were obtained by extracting them from 50 bovine skulls. The teeth used in the study were of comparable size (Figure 1). They were immersed in $1 \%$ chloramine for $24 \mathrm{~h}$ at room temperature to disinfect them. The teeth were cleansed of sediment and plaques. We excluded all teeth with dental abnormalities or caries. We used a diamond drill with water cooling to cut the crowns of the teeth from the roots, $2 \mathrm{~mm}$ below the cement enamel junction. The pulp tissue was removed with a barbed broach via a cervical cut. The labial wall thickness of the tooth chamber was standardized to $2 \mathrm{~mm}$. The samples were eventually immersed in saline $(0.9 \% \mathrm{NaCl})$ to neutralize the environment. We randomly assigned the teeth to five experimental, one positive, and one negative control groups, each containing 10 teeth. The sample size calculation was performed in $G^{*}$ Power 3.1 software (Heinrich-Heine-Universität Düsseldorf, Dusseldorf, Germany). The materials to be evaluated included Biodentine (Septodont, Saint-Maur-des-Fossés Cedex, France), Ortho MTA (BioMTA, Seoul, Korea), Retro MTA (BioMTA, Seoul, Korea), MTA Plus (compounded by PrevestDenpro, Jammu, India for Avalon Biomed Inc., Bradenton, FL, USA), and MTA Repair HP (Angelus, Londrina, PR, Brazil). We sealed the teeth using white ProRoot MTA (Dentsply, Tulsa, OK, USA) in the positive group, because of its proven discolouration effect. In contrast, we used glass ionomer for sealing the negative samples. All materials were prepared according to the manufacturer's recommendations (Table 1). They were then retrofilled with 2-mm deep cavities in prepared pulp chambers. Following the initial setting time (Biodentine-12 min, Ortho MTA-5 h, Retro MTA-3 min, MTA Plus-15 min, MTA Repair HP-15 min, ProRoot MTA-4 h), the cervical area was sealed with glass ionomer. All samples were stored in a dark environment, in an incubator $(220 \mathrm{~V}, 50 \mathrm{~Hz}$, Carbolab Electronic, Warsaw, Poland) at $100 \%$ humidity and $37^{\circ} \mathrm{C}$ throughout the study period. Table 1 summarises the compositions of CSCs that were used in the study. 


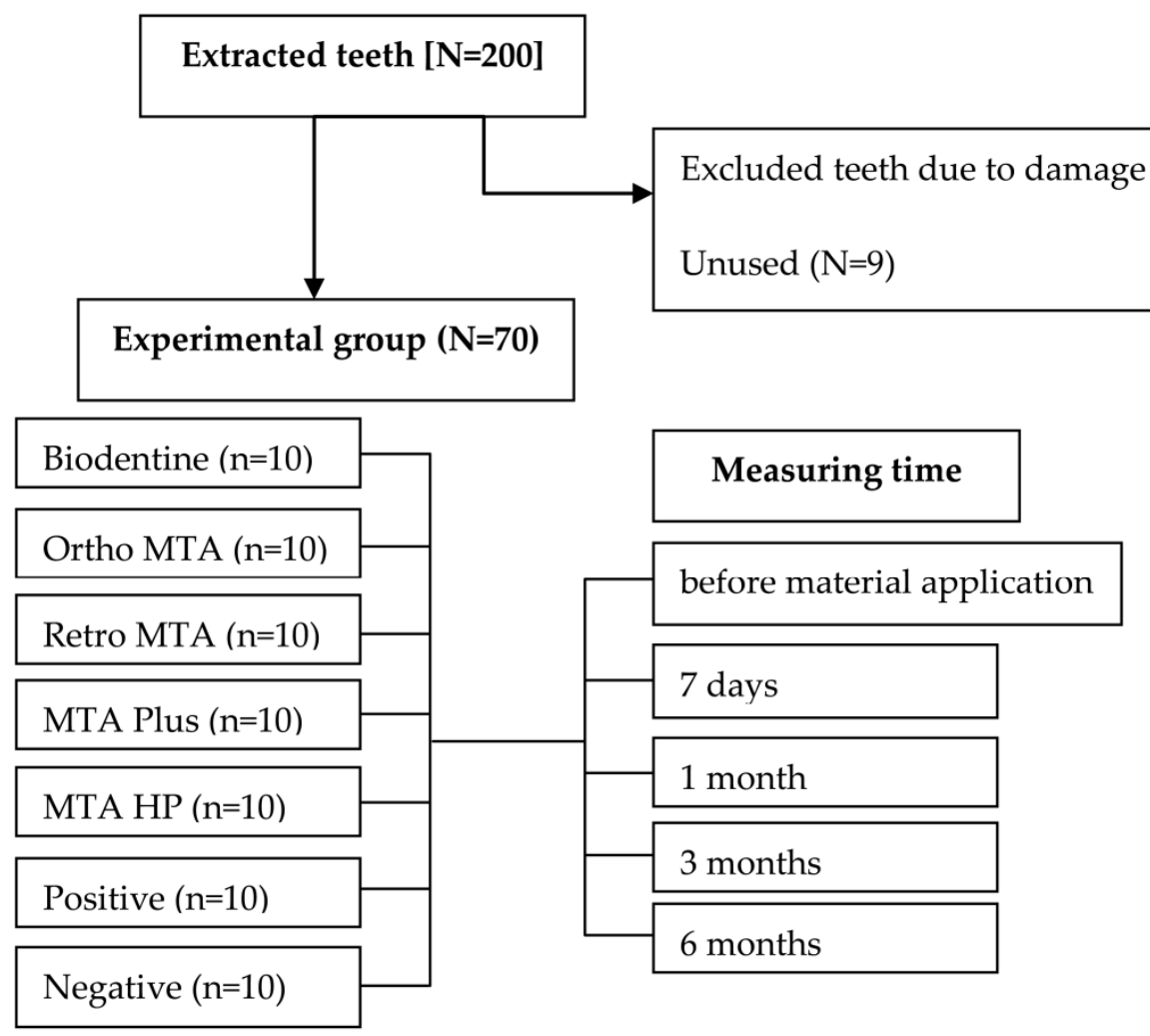

Figure 1. Description of experimental groups.

Table 1. Compositions of the CSCs considered in this study.

\begin{tabular}{|c|c|c|c|}
\hline Material & Manufacturer & Ingredients-Radiopacifer & Mixing \\
\hline Biodentine & $\begin{array}{l}\text { Septodont, Saint-Maur-des-Fossés } \\
\text { Cedex, France }\end{array}$ & $\begin{array}{l}\text { powder: tricalcium silicate, } \\
\text { dicalcium silicate, calcium } \\
\text { carbonate and oxide filler, iron } \\
\text { oxide shade, and zirconium oxide } \\
\text { liquid: calcium chloride as } \\
\text { accelerator, hydrosoluble polymer } \\
\text { water-reducing agent, water }\end{array}$ & $\begin{array}{l}0.7 \mathrm{~g} \text { capsule of powder }+5 \text { drops } \\
\text { of liquid ( } 30 \mathrm{~s} ; 4000-4200 \mathrm{rpm})\end{array}$ \\
\hline Ortho MTA & BioMTA, Seoul, Korea & $\begin{array}{l}\text { calcium carbonate, silicon dioxide, } \\
\text { aluminium oxide, and } \\
\underline{\text { dibismuth trioxide }}\end{array}$ & $\begin{array}{l}0.2 \mathrm{~g} \text { pouches of powder }+2 \\
\text { drops of water (mixed manually) }\end{array}$ \\
\hline Retro MTA & BioMTA, Seoul, Korea & $\begin{array}{l}\text { calcium carbonate, silicon dioxide, } \\
\text { aluminium oxide, and } \\
\text { calcium zirconia complex }\end{array}$ & $\begin{array}{l}0.3 \mathrm{~g} \text { pouches of powder }+3 \\
\text { drops of water (mixed manually) }\end{array}$ \\
\hline MTA Plus & $\begin{array}{l}\text { Avalon Biomed Inc, by Prevest } \\
\text { Denpro Limited, Jammu, India }\end{array}$ & $\begin{array}{l}\text { powder: tricalcium silicate, } \\
\text { dicalcium silicate, bismuth oxide, } \\
\text { calcium sulfate, and silica } \\
\text { liquid: hydrated polymer gel } \\
\text { powder: tricalcium silicate, }\end{array}$ & $\begin{array}{l}\text { Powder }+ \text { liquid (mixed } \\
\text { manually) }\end{array}$ \\
\hline MTA Repair HP & Angelus, Londrina, PR, Brazil & $\begin{array}{l}\text { dicalcium silicate, tricalcium } \\
\text { aluminate, calcium oxide, and } \\
\text { calcium tungstate } \\
\text { liquid: water and plasticizer }\end{array}$ & $\begin{array}{l}0.085 \mathrm{~g} \text { capsules of powder }+2 \\
\text { drops of liquid (mixed manually) }\end{array}$ \\
\hline ProRoot MTA & Dentsply, Tulsa, OK, USA & $\begin{array}{l}\text { tricalcium silicate, dicalcium } \\
\text { silicate, tricalcium aluminate, } \\
\text { tetracalcium aluminoferrite, free } \\
\text { calcium oxide, and bismuth oxide }\end{array}$ & $\begin{array}{l}0.5 \mathrm{~g} \text { pouches of powder }+ \\
\text { pre-measured unit dose of water } \\
\text { (mixed manually) }\end{array}$ \\
\hline
\end{tabular}




\subsection{Measuring Tooth Discolouration}

The measurements were done by two blinded operators (JM and IF) using a VITA Easyshade Compact 5.0 (VITA Zahnfabrik, Bad Säckingen, Germany) spectrophotometer in a dark room, under constant conditions. The moulds $(30 \mathrm{~mm} \times 36 \mathrm{~mm})$ were made for each sample using a impression material (Aquasil Soft Putty, Dentsply DeTrey, Konstanz, Germany). Moreover, holes corresponding to the size of the VITA colour measurement device tip ( $\varnothing 6 \mathrm{~mm}$ ) were created in the moulds. The extent of discolouration was measured at the same location in the cervical third of the labial surface (Figure 2).

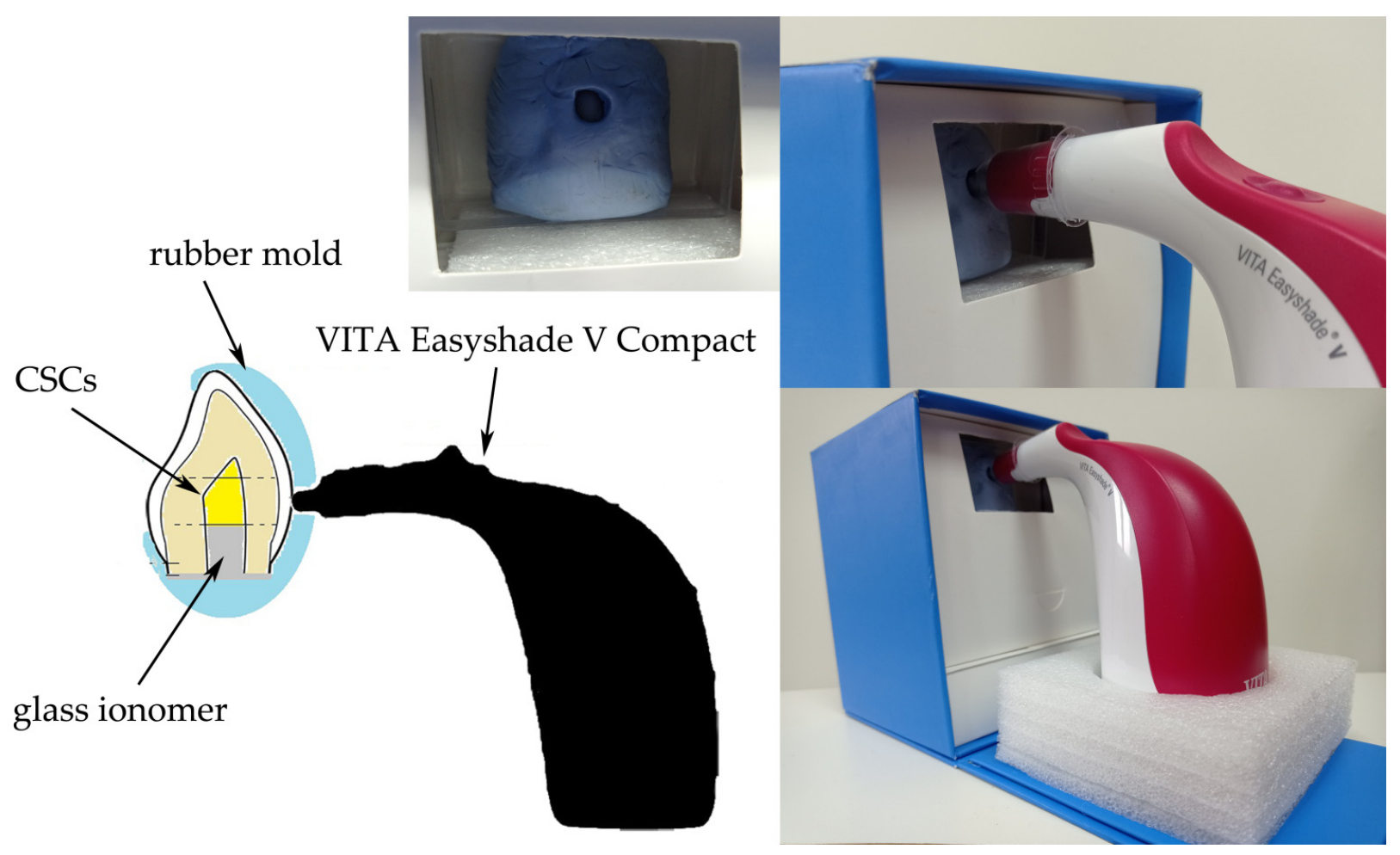

Figure 2. A schematic representation of the setup for colour measurement.

All teeth were dried with a blower for $3 \mathrm{~s}$ before measurement. This prevented light refraction and erroneous readings. We calibrated the device before each measurement and repeated the readings thrice. Instrument was placed in the calibration holder so that the probe tip was flush and perpendicular to the calibration block and depressed the calibration switch. The change in tooth colour was measured before the material placement $(\mathrm{t} 0)$, after 1 week (t1), 1 month (t2), 3 months ( $\mathrm{t} 3$ ), and 6 months (t4). Moreover, we compared the differences in the colouration under the influence of the materials with the $\Delta \mathrm{E}$ values in the CIE Lab colour space using visual spectrophotometry. Each colour is mathematically described by the following three components: $\mathrm{L}$, or lightness, which ranges from 0 (black) to 100 (white); $a$, or colour ranging from green to red; and b, or colour ranging from blue to yellow. $\Delta \mathrm{E}$ values represent the difference between the final and baseline values. $\Delta \mathrm{E}$ was calculated by the following equation: [29]

$$
\Delta \mathrm{E}=\sqrt{\left(L_{2}-L_{1}\right)^{2}+\left(a_{2}-a_{1}\right)^{2}+\left(b_{2}-b_{1}\right)^{2}}
$$

We used our own scale to clinically evaluate the colour changes. These changes were defined as follows: $\mathrm{A}=$ no change $\mathrm{B}=\mathrm{a}$ darker shade of base colour, and $\mathrm{C}=\mathrm{a}$ grey shade. We used an EyeSpecial C-II (Shofu, Inc., Kyoto, Japan-exposure: 1000 s; aperture f/8.2; focal distance $32 \mathrm{~mm}$; ISO-100) to document the test results at each stage. It is an automatic SHOFU Japanese device, solely dedicated to capturing the teeth and mouth of a patient. 


\subsection{Statistical Analyses}

Statistical analyses were performed using STATA 11 (StataCorp LLC, College Station, TX, USA). We conducted Kolmogorov-Smirnov tests to assess the compatibility of distributions with the normal distribution. Moreover, the Student's $t$-test and Mann-Whitney U test were used for comparing the materials' discolouration and changes over time within each group. To analyze the interobserver and intraobserver agreement between measurements, we calculated the intraclass correlation coefficient (ICC) between the measurements taken by two researchers and between two measurements taken by the same researcher for all samples. The significance levels were set at $p<0.05$ (95\% level of confidence) for all comparisons.

\section{Results}

The results of $\Delta \mathrm{E}$ and $\Delta \mathrm{L}$ are presented in Figures 3 and 4, respectively. Similar letters indicate statistically significant differences between different time points within a material group $(p<0.05)$. $p$-values obtained from comparing groups of materials at different measuring times $(p<0.05)$ are presented in Table 2. Ortho MTA and MTA Plus specimens revealed visible discolouration after 7 days $(\Delta \mathrm{E} \geq 3.7 ; p<0.05)$. The negative specimens were the only ones that did not show discolouration beyond the clinically perceptible limits $(\Delta \mathrm{E} \geq 3.7)$ in any of the study periods. The maximum changes $(\Delta \mathrm{E}>6)$ were observed after 6 months for Ortho MTA $(p=0.0015)$, ProRoot MTA $(p=0.0012)$, MTA Plus $(p=0.0343)$, and Biodentine $(p=0.0065)$. Moreover, the biggest change in the $\Delta \mathrm{L}$ parameter was observed after 6 months for Ortho MTA and MTA Plus $(p=0.0002)$. On observing with the naked eye, we found grey colouration of the tooth tissues for the ProRoot MTA, Ortho MTA, and MTA Plus. In contrast, Biodentine darkened the shade of the base colour of the tooth (Figure 5, Table 3). Significant differences in $\Delta \mathrm{E}$ were found between each of the materials and the negative group after 6 months $(p=0.0000)$. Tooth discolourations $(\Delta \mathrm{E})$ using ProRoot MTA, Biodentine, Ortho MTA, and Retro MTA were statistically significant after 3 and 6 months. We observed a significant colour difference after 6 months for MTA Plus, compared with 1 month for MTA Repair HP. On comparing the brightness parameter $(\Delta \mathrm{L})$, Retro MTA did not reveal any significant difference from the negative group after 6 months. The difference in $\Delta \mathrm{L}$ was significant after 1,3 , and 6 months for all the materials. Repeatability of measurements calculated as ICC was excellent both between two researchers (interobserver agreement: ICC $=0.994$ ) and between two measurements made by the same researcher (intraobserver agreement: ICC $>0.9$ for investigator JM and ICC $>0.9$ for investigator IF).

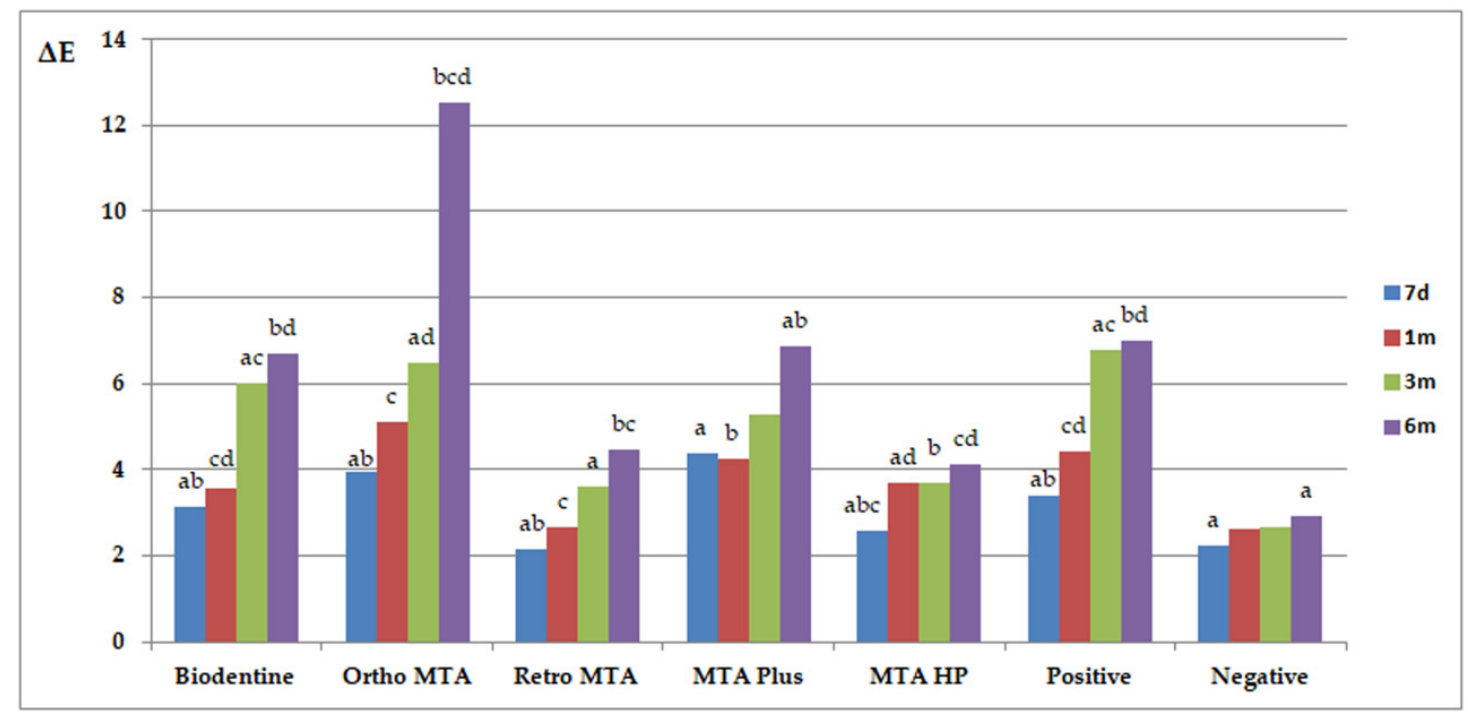

Figure 3. Mean $\Delta \mathrm{E}$ values of tooth discolouration for different durations Similar letters indicate statistically significant 
differences between different time points within a material group $(p<0.05)$; Biodentine (a 0.0041; b 0.0065; c 0.0191; d 0.0191); Ortho MTA (a 0.0284; b 0.0015; c 0.0052; d 0.0284); Retro MTA (a 0.0413; b 0.0073; c 0.0493); MTAPlus (a 0.0343; b 0.0065); positive (a 0.0032; b 0.0012; c 0.0494; d 0.0102); negative (a 0.0126).

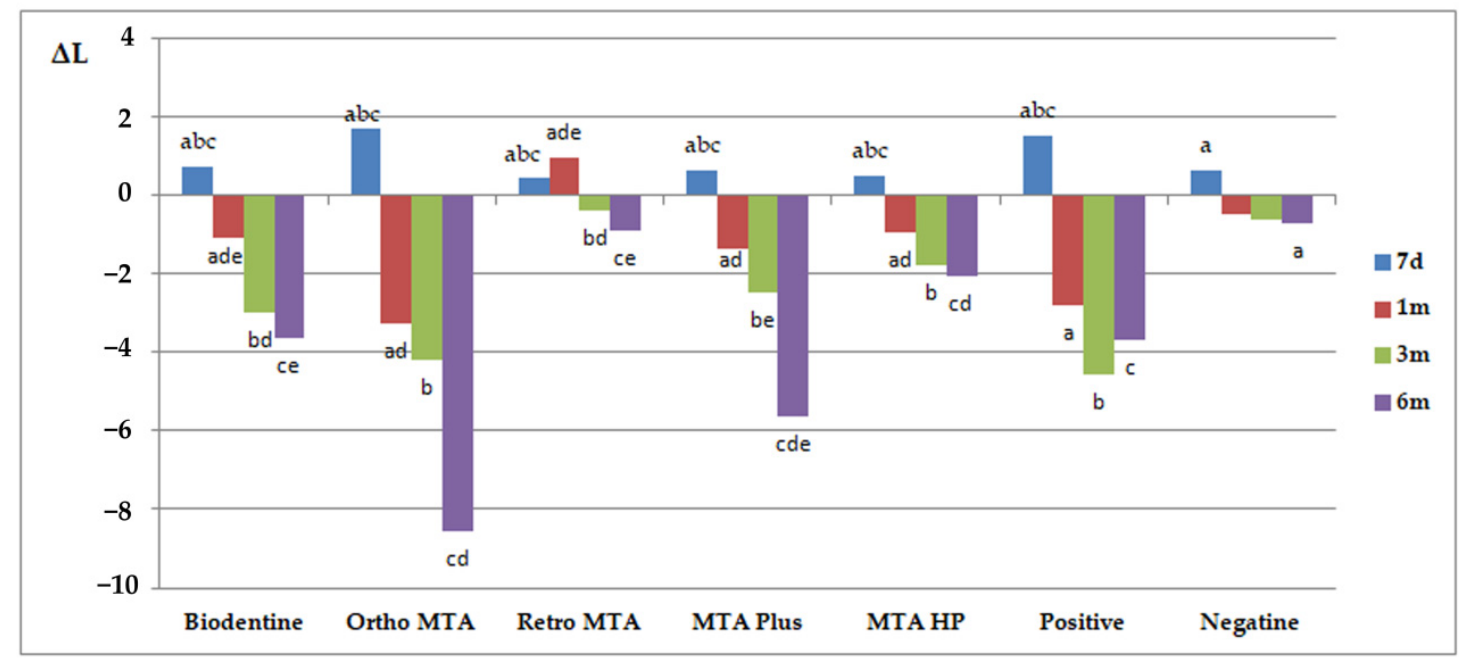

Figure 4. Mean $\Delta \mathrm{L}$ values of tooth discolouration for different durations. Similar letters indicate statistically significant differences between different time points within a material group $(p<0.05)$; Biodentine $(\mathrm{a} 0.0311 ; \mathrm{b} 0.0022 ; \mathrm{c} 0.0011 ; \mathrm{d}$ 0.0448; e 0.0257); Ortho MTA (a 0.0002; b 0.0004; c 0.0002; d 0.0394); Retro MTA (a 0.0363; b 0.0486; c 0.0209; d 0.0171; e 0.0126); MTAPlus (a 0.0126; b 0.0081; c 0.0002; d 0.0012; e 0.0310); positive (a 0.0002; b 0.0002; c 0.0004); negative (a 0.0171).

Table 2. $p$-Values obtained from comparing groups of materials at different measuring times $(p<0.05)$.

\begin{tabular}{|c|c|c|c|c|c|c|c|}
\hline & & Ortho MTA & Retro MTA & MTA Plus & МТА HP & Positive & Negative \\
\hline \multirow{4}{*}{ Biodentine } & $7 d$ & & & & & & 0.0202 \\
\hline & $1 \mathrm{~m}$ & & & & & & \\
\hline & $3 \mathrm{~m}$ & & 0.0321 & & 0.0230 & & 0.0020 \\
\hline & $6 \mathrm{~m}$ & 0.0348 & & & 0.0231 & & 0.0017 \\
\hline \multirow{4}{*}{ Ortho MTA } & $7 d$ & & & & & & \\
\hline & $1 \mathrm{~m}$ & & & & & & 0.0178 \\
\hline & $3 \mathrm{~m}$ & & & & 0.0065 & & 0.0003 \\
\hline & $6 \mathrm{~m}$ & & & 0.0420 & 0.0021 & 0.0331 & 0.0007 \\
\hline \multirow{4}{*}{ Retro MTA } & $7 d$ & & & 0.0124 & & & \\
\hline & $1 \mathrm{~m}$ & 0.0311 & & 0.0049 & 0.0423 & 0.0174 & \\
\hline & $3 \mathrm{~m}$ & 0.0494 & & 0.0267 & & 0.0100 & \\
\hline & $6 \mathrm{~m}$ & 0.0034 & & & & 0.0021 & 0.0095 \\
\hline \multirow{4}{*}{ MTA Plus } & $7 \mathrm{~d}$ & & & & 0.0336 & & 0.0080 \\
\hline & $1 \mathrm{~m}$ & & & & & & 0.0000 \\
\hline & $3 \mathrm{~m}$ & & & & 0.0071 & & 0.0001 \\
\hline & $6 \mathrm{~m}$ & & & & 0.0218 & & 0.0019 \\
\hline \multirow{4}{*}{ MTA HP } & $7 d$ & & & & & & \\
\hline & $1 \mathrm{~m}$ & & & 0.0129 & & & 0.0000 \\
\hline & $3 \mathrm{~m}$ & & & & & 0.0067 & 0.0001 \\
\hline & $6 \mathrm{~m}$ & & & & & 0.0000 & 0.0002 \\
\hline \multirow{4}{*}{ Positive } & $7 \mathrm{~d}$ & & & & & & 0.0383 \\
\hline & $1 \mathrm{~m}$ & & & & & & 0.0027 \\
\hline & $3 \mathrm{~m}$ & & & & & & 0.0007 \\
\hline & $6 \mathrm{~m}$ & & & & & & 0.0000 \\
\hline
\end{tabular}




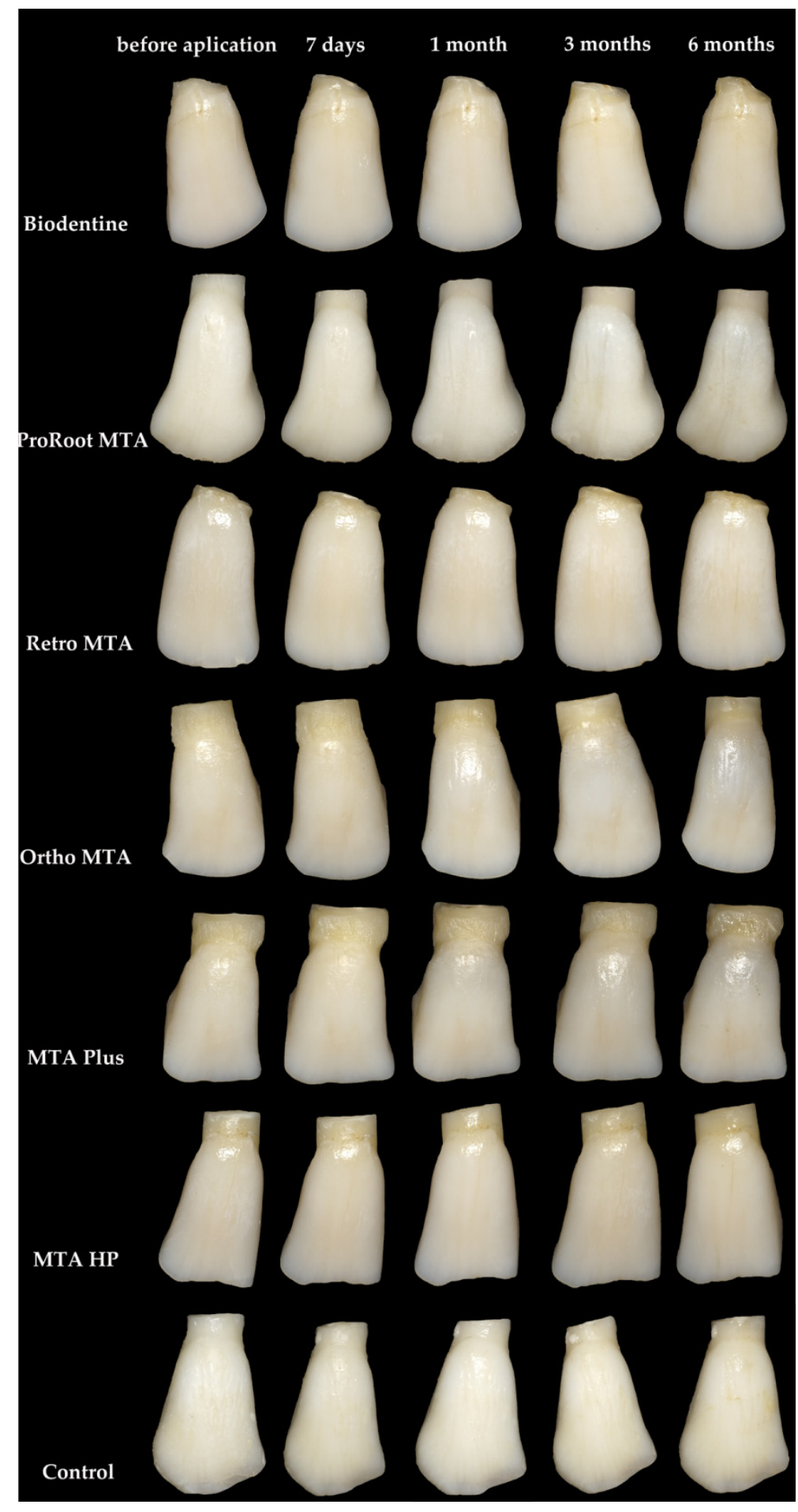

Figure 5. Representation of the bovine teeth samples. 
Table 3. Clinical evaluation of the changes in teeth colour.

\begin{tabular}{|c|c|c|c|c|c|}
\hline \multirow{2}{*}{ Material } & \multirow{2}{*}{$\begin{array}{l}\text { Colour } \\
\text { Scale }\end{array}$} & \multicolumn{4}{|c|}{ Study Time } \\
\hline & & $7 \mathrm{~d}$ & $1 \mathrm{~m}$ & $3 \mathrm{~m}$ & $6 \mathrm{~m}$ \\
\hline & A & 10 & 10 & 7 & 2 \\
\hline \multirow[t]{3}{*}{ Biodentine } & $\mathrm{B}$ & 0 & 0 & 3 & 8 \\
\hline & $\mathrm{C}$ & 0 & 0 & 0 & 0 \\
\hline & $\mathrm{A}$ & 10 & 3 & 0 & 0 \\
\hline \multirow[t]{3}{*}{ Ortho MTA } & B & 0 & 0 & 0 & 0 \\
\hline & $\mathrm{C}$ & 0 & 7 & 10 & 10 \\
\hline & $\mathrm{A}$ & 10 & 10 & 10 & 10 \\
\hline \multirow[t]{3}{*}{ Retro MTA } & B & 0 & 0 & 0 & 0 \\
\hline & $\mathrm{C}$ & 0 & 0 & 0 & 0 \\
\hline & A & 10 & 10 & 3 & 1 \\
\hline \multirow{3}{*}{ MTA Plus } & B & 0 & 0 & 0 & 0 \\
\hline & $\mathrm{C}$ & 0 & 0 & 7 & 9 \\
\hline & $\mathrm{A}$ & 10 & 10 & 10 & 10 \\
\hline \multirow[t]{3}{*}{ MTA Repair HP } & $\mathrm{B}$ & 0 & 0 & 0 & 0 \\
\hline & $\mathrm{C}$ & 0 & 0 & 0 & 0 \\
\hline & A & 10 & 9 & 5 & 0 \\
\hline \multirow[t]{3}{*}{ Positive } & $\mathrm{B}$ & 0 & 0 & 0 & 0 \\
\hline & $\mathrm{C}$ & 0 & 1 & 5 & 10 \\
\hline & A & 10 & 10 & 10 & 10 \\
\hline \multirow{2}{*}{ Negative } & B & 0 & 0 & 0 & 0 \\
\hline & C & 0 & 0 & 0 & 0 \\
\hline
\end{tabular}

Scale of colour assessment: $\mathrm{A}=$ no change, $\mathrm{B}=$ darker shade of base colour, and $\mathrm{C}=$ grey shade.

\section{Discussion}

The colour of teeth is not only associated with dental aesthetics but also with the general well-being of a patient in mind. The colour of natural teeth is determined by a combination of the following parameters: light scattered in the enamel and dentine, contribution of the enamel backing reflectance, the condition of the light under which the tooth is observed, and light reflected from the enamel surface and surrounding environment [30]. The aesthetics of dentition are influenced by the materials used, the final filling, as well as the general condition, hygiene and health of the soft and hard tissues. The biological interactions between restorative materials and the overlying biofilm are key factors in the longevity of the restorations, secondary caries, and, thus, unsightly discoloration of the teeth $[31,32]$.

Our methodology was similar to that mentioned by Valles et al. [33] and Ramos et al. [34]. We did not immerse the tooth samples in sodium hypochlorite to eliminate the risk of interaction of the material with the fluid in the dentine tubules. Therefore, our study differed from the earlier ones in the aforementioned aspect. The ready availability of bovine dentine promoted their selection. Human and bovine teeth tissues have similar composition, morphology, and physical properties [35]. Moreover, the number of dentinal tubules per $\mathrm{mm}^{2}$ and the diameter are reportedly similar between bovine incisors and human molars [35]. The transdentinal permeability characteristics of bovine dentine at the cementoenamel junction are smaller than that of the human dentine [36]. Hence, the colour changes in human teeth are supposedly greater.

Based on the spectrophotometric results, null hypothesis was accepted. All materials significantly changed the colour of the teeth $(p<0.05)$. Nonetheless, the maximum changes were observed after 6 months for the Ortho MTA, ProRoot MTA, MTA Plus, and Biodentine $(\Delta \mathrm{E}>6)$. As judged by the naked-eye, Retro MTA and MTA Repair HP did not affect the stability of tooth colour. Moreover, we observed an increase in discolouration over time in all cases. Researchers have reported the high discolouration potential of ProRoot MTA [33,34,37-41] and Ortho MTA [41]. Moreover, the influence of Retro MTA [37] and MTA Repair HP [42] has been associated with no discolouration. The above-mentioned materials caused discolouration below the clinically perceptible limit. $\Delta \mathrm{E}$ for these materials 
was slightly less than four after 6 months. Thus, these discolourations are irrelevant to visual perception. In addition, we noticed a change of $\Delta \mathrm{E}$ in the Biodentine group after 3 and 6 months. Nonetheless, there was no noticeable grey discolouration and the tooth was more intensely yellow. There is inconclusive evidence for the effects of the aforementioned materials on teeth colour. Biodentine resulted in the discolouration of tooth tissues after 6 weeks $(\Delta \mathrm{E}=4.95[43]), 4$ months $(\Delta \mathrm{E}=5.28$ [33] $), 6$ months $(\Delta \mathrm{E}=2.33$ [42] $)$, and 12 months $(\Delta \mathrm{E}=10.83$ [34], $\Delta \mathrm{E}=4$ [44]). A subtle yellow discolouration is supposedly less significant than a grey or black discolouration. The results of other studies on Biodentine discoloration are very divergent. Most authors prove that Biodentine does not affect tooth discoloration as much as MTA $[34,41,44,45]$. In another study, the color change caused by Biodentine was much greater than by MTA [43]. In our study, the tooth tissues were not rinsed with $\mathrm{NaOCl}$, which could significantly minimize $\mathrm{MTA}$ discoloration. $\mathrm{NaOCl}$ is routinely used in endodontics for irrigating root canals. It was shown that residues of $\mathrm{NaOCl}$ could penetrate into dentin, and it was very difficult to remove from root canals. $\mathrm{NaOCl}$ changes the color of CSCs containing bismuth oxide [46]. When $\mathrm{NaOCl}$ came into contact with bismuth and other heavy metal oxides, a black precipitation appeared. Hypochlorite is not essential for discolouration to occur, although its effect is very marked [47].

There are reports on the staining potential of materials that contain bismuth oxide. It produces bismuth carbonate upon interacting with collagen or after oxidisation. This is achieved by its contact with carbon dioxide in the air. Moreover, an exposure to light irradiation or high temperatures in an oxygen-free environment leads to its dissociation from the material. This eventually produces metallic bismuth, thus causing discolouration. Due to this, all treatments with the use of light, such as whitening, restorations with light-cured composite materials, or treatments with using lasers, e.g., in periodontal diseases, may significantly change the color of a tooth filled with calcium silicate-based cements [32,36,47-50]. Moreover, bismuth oxide present in dental cements adversely affects the stem cells of the dental pulp. This in turn might induce cell death or cause a change in viability, besides increasing the risk of irreversible pulpitis [51].

Biodentine and Retro MTA comprise a contrasting zirconium oxide as a radiopacifier. These materials have a low staining potential, as seen in the current study $[37,43,44]$. In addition, MTA Repair HP comprises calcium tungstate as the contrasting agent. We found that the aforementioned material does not cause visible tooth discolouration. The original colour of the material is slightly blue after mixing. Moreover, it might exert a positive effect on the visual perception of the tooth colour.

In addition, previous studies have shown that the presence of blood is a factor that greatly enhances the color change of CSCs. The increase in blood discoloration may be related to the porosity of the material and the absence or presence of a smear layer, which may increase or reduce dentin permeability, respectively. Due to the fact that MTA has a long setting time, it remains porous longer, resulting in increased blood absorption followed by hemolysis. Therefore, it can cause more discoloration than, for example, Biodentine [52]. In the presence of blood, teeth discolor by more than $15 \%$ in just $24 \mathrm{~h}$. The amount of change depends on the type of material used and the passage of time [25,53]. Tooth discoloration is the most noticeable in regenerative endodontics, where the biomaterial is in the direct contact with blood. Regenerative endodontics studies the potential for the regeneration of damaged pulp as well as the creation and delivery of replacement pulp-dentin tissues, and belongs in category of stem cell induction therapies. A blood clot formed inside the canal could affect the colour of the teeth $[54,55]$. The use of platelet-rich concentrates and transplanting stem cells into the tooth cavity can also have a significant impact on tooth discoloration, but this requires confirmation by research. In regenerative endodontics, in addition to biomaterials and the presence of blood, antibiotic pastes used to disinfect the root canal have a significant impact on the tooth color change [10].

Our statistical results show that the Ortho MTA, ProRoot MTA, MTA Plus, and Biodentine materials were associated with chromogenic effects. Their application should be avoided in the pulp chamber of the aesthetic zone, particularly in young people. This 
caution can be attributed to the significance of the appearance of their teeth on their social development.

Regarding the limitations of the present study, there is a need to conduct clinical trials in the patient's mouth in all kinds of vital pulp therapies. A longer follow-up period is desirable to confirm the obtained results over a long-term perspective. This in-vitro study was not identical to clinical condition. Other variables not accounted for in this study might play a noteworthy role on tooth discoloration, for example, the presence of blood, contact with irrigation fluids, and exposure to light. More clinical trials and longer-term studies are needed to confirm these results and provide information on the mechanisms involved in CSCs and subsequent tooth discoloration.

\section{Conclusions}

Unless required by the therapeutic procedure, clinicians should pay attention to the fact that the CSCs may affect the tooth discoloration. In conclusion, Retro MTA and MTA Repair HP exhibited less discolouration than ProRoot MTA, Biodentine, Ortho MTA, and MTA Plus. In addition, Retro MTA, MTA Repair HP can be safely used in the aesthetic zone of the human dentition. According to clinical results, the possibility of using Biodentine, due to the lack of gray discoloration, can be considered.

Author Contributions: Conceptualisation, J.M.; methodology, J.M., I.F. and A.N.; writing-original draft preparation, J.M., M.M. and A.N.; writing—review and editing, J.M., I.F. and A.N.; visualisation, J.M. and M.M.; and supervision, A.N. All authors have read and agreed to the published version of the manuscript.

Funding: The research was supported by the Polish Ministry of Science and Higher Education program for the years 2017-2020 and by The Faculty of Medicine \& Dentistry, Pomeranian Medical University in Szczecin (grant no. MB-262-223/17), Poland.

Institutional Review Board Statement: The study was conducted according to the guidelines of the Declaration of Helsinki, and approved by the Ethics Committee of the Pomeranian Medical University, Poland (ethic reference KB-0012/80/16 dated 27 June 2016).

Informed Consent Statement: Not applicable.

Acknowledgments: This article is an original work that has not been published before. It is not being considered for publication elsewhere in its current form, either in printed or electronic media.

Conflicts of Interest: The authors declare no conflict of interest. The funders had no role in the design of the study, data collection, analyses, interpretation of data, writing of the manuscript, or decision to publish the results.

\section{References}

1. Santos, J.; Pereira, J.; Marques, A.; Sequeira, D.; Friedman, S. Vital pulp therapy in permanent mature posterior teeth with symptomatic irreversible pulpitis: A systematic review of treatment outcomes. Med. Kaunas 2021, 57, 573. [CrossRef]

2. Ricucci, D.; Siqueira, J.F.; Li, Y.; Tay, F.R. Vital pulp therapy: Histopathology and histobacteriology-based guidelines to treat teeth with deep caries and pulp exposure. J. Dent. 2019, 86, 41-52. [CrossRef] [PubMed]

3. Naseri, M.; Khayat, A.; Zamaheni, S.; Shojaeian, S. Correlation between histological status of the pulp and its response to sensibility tests. Iran. Endod. J. 2017, 12, 20-24. [CrossRef] [PubMed]

4. Ghoddusi, J.; Forghani, M.; Parisay, I. New approaches in vital pulp therapy in permanent teeth. Iran. Endod. J. 2014, 9, 15-22. [PubMed]

5. Palma, P.J.; Marques, J.A.; Antunes, M.; Falacho, R.I.; Sequeira, D.; Roseiro, L.; Santos, J.M.; Ramos, J.C. Effect of restorative timing on shear bond strength of composite resin/calcium silicate-based cements adhesive interfaces. Clin. Oral Investig. 2021, 25, 3131-3139. [CrossRef] [PubMed]

6. American Association of Endodontists Glossary of Endodontic Terms, 9th ed., Chicago, IL, USA. Available online: http: //www.aae.org/clinical-resources/aae-glossary-of-endodontic-terms.aspx (accessed on 11 February 2020).

7. Qudeimat, M.A.; Alyahya, A.; Hasan, A.A. Mineral trioxide aggregate pulpotomy for permanent molars with clinical signs indicative of irreversible pulpitis: A preliminary study. Int. Endod. J. 2017, 50, 126-134. [CrossRef]

8. Taha, N.A.; Ahmad, M.B.; Ghanim, A. Assessment of Mineral Trioxide Aggregate pulpotomy in mature permanent teeth with carious exposures. Int. Endod. J. 2017, 50, 117-125. [CrossRef] 
9. Meza, G.; Urrejola, D.; Saint Jean, N.; Inostroza, C.; López, V.; Khoury, M.; Brizuela, C. Personalized cell therapy for pulpitis using autologous dental pulp stem cells and leukocyte platelet-rich fibrin: A case report. J. Endod. 2019, 45, 144-149. [CrossRef]

10. Fagogeni, I.; Metlerska, J.; Lipski, M.; Falgowski, T.; Maciej, G.; Nowicka, A. Materials used in regenerative endodontic procedures and their impact on tooth discoloration. J. Oral Sci. 2019, 61, 379-385. [CrossRef] [PubMed]

11. Tetè, G.; D’Orto, B.; Nagni, M.; Agostinacchio, M.; Polizzi, E.; Agliardi, E. Role of induced pluripotent stem cells (IPSCS) in bone tissue regeneration in dentistry: A narrative review. J. Biol. Regul. Homeost. Agents 2020, 34, 1-10. [PubMed]

12. Duncan, H.F.; Cooper, P.R.; Smith, A.J. Dissecting dentine-pulp injury and wound healing responses: Consequences for regenerative endodontics. Int. Endod. J. 2019, 52, 261-266. [CrossRef]

13. Huang, G.T.; Liu, J.; Zhu, X.; Yu, Z.; Li, D.; Chen, C.A.; Azim, A.A. Pulp/dentin regeneration: It should be complicated. J. Endod. 2020, 46, S128-S134. [CrossRef]

14. Paula, A.B.; Laranjo, M.; Marto, C.-M.; Paulo, S.; Abrantes, A.M.; Casalta-Lopes, J.; Marques-Ferreira, M.; Botelho, M.F.; Carrilho, E. Direct pulp capping: What is the most effective therapy?-Systematic review and meta-analysis. J. Evid. Based. Dent. Pract. 2018, 18, 298-314. [CrossRef]

15. Prosser, H.J.; Groffman, D.M.; Wilson, A.D. The effect of composition on the erosion properties of calcium hydroxide cements. J. Dent. Res. 1982, 61, 1431-1435. [CrossRef]

16. Hilton, T.J.; Ferracane, J.L.; Mancl, L. Northwest practice-based research collaborative in evidence-based dentistry (NWP). comparison of $\mathrm{CaOH}$ with MTA for direct pulp capping: A PBRN randomized clinical trial. J. Dent. Res. 2013, 92, 16S-22S. [CrossRef]

17. Holland, R.; De Souza, V.; Murata, S.S.; Nery, M.J.; Bernabé, P.F.; Filho, J.A.O.; Junior, E.D. Healing process of dog dental pulp after pulpotomy and pulp covering with mineral trioxide aggregate or Portland cement. Braz. Dent. J. 2001, 12, 109-113. [PubMed]

18. Eidelman, E.; Holan, G.; Fuks, A.B. Mineral trioxide aggregate vs. formocresol in pulpotomized primary molars: A preliminary report. Pediatr. Dent. 2001, 23, 15-18. [PubMed]

19. Camilleri, J. Modification of mineral trioxide aggregate. Physical and mechanical properties. Int. Endod. J. 2008, 41, 843-849. [CrossRef] [PubMed]

20. Camilleri, J. The chemical composition of mineral trioxide aggregate. J. Conserv. Dent. 2008, 11, 141-143. [CrossRef] [PubMed]

21. Gomes-Cornélio, A.L.; Rodrigues, E.M.; Mestieri, L.B.; Falcoski Tde, O.; Soares, C.P.; Guerreiro-Tanomaru, J.M.; Rossa, C.J.; Tanomaru, M.F. Cytotoxicity and genotoxicity of calcium silicate-based cements on an osteoblast lineage. Braz. Oral Res. 2016, 30, S1806-83242016000100247. [CrossRef] [PubMed]

22. Torabinejad, M.; Parirokh, M. Mineral trioxide aggregate: A comprehensive literature review-part II: Leakage and biocompatibility investigations. J. Endod. 2010, 36, 190-202. [CrossRef]

23. Parirokh, M.; Torabinejad, M. Mineral trioxide aggregate: A comprehensive literature review-Part III: Clinical applications, drawbacks, and mechanism of action. J. Endod. 2010, 36, 400-413. [CrossRef]

24. Nowicka, A.; Wilk, G.; Lipski, M.; Kołecki, J.; Buczkowska-Radlińska, J. Tomographic evaluation of reparative dentin formation after direct pulp capping with $\mathrm{Ca}(\mathrm{OH}) 2$, MTA, Biodentine, and dentin bonding system in human teeth. J. Endod. 2015, 41, 1234-1240. [CrossRef]

25. Możyńska, J.; Metlerski, M.; Lipski, M.; Nowicka, A. Tooth discoloration induced by different calcium silicate-based cements: A systematic review of in vitro studies. J. Endod. 2017, 43, 1593-1601. [CrossRef] [PubMed]

26. Dawood, A.E.; Parashos, P.; Wong, R.H.K.; Reynolds, E.C.; Manton, D.J. Calcium silicate-based cements: Composition, properties, and clinical applications. J. Investig. Clin. Dent. 2017, 8, e12195. [CrossRef]

27. Gandolfi, M.G.; Siboni, F.; Primus, C.M.; Prati, C. Ion release, porosity, solubility, and bioactivity of MTA Plus tricalcium silicate. J. Endod. 2014, 40, 1632-1637. [CrossRef] [PubMed]

28. Guimarães, B.M.; Prati, C.; Duarte, M.A.H.; Bramante, C.M.; Gandolfi, M.G. Physicochemical properties of calcium silicate-based formulations MTA Repair HP and MTA Vitalcem. J. Appl. Oral Sci. 2018, 26, e2017115. [CrossRef] [PubMed]

29. International Commission on Illumination. Recommendations on Uniform Color Spaces, Color-Difference Equations, Psychometric Color Terms; Bureau Central de la CIE: Paris, France, 1978; p. 1913.

30. Karamouzos, A.; Papadopoulos, M.A.; Kolokithas, G.; Athanasiou, A.E. Precision of in vivo spectrophotometric colour evaluation of natural teeth. J. Oral Rehabil. 2007, 34, 613-621. [CrossRef] [PubMed]

31. Cazzaniga, G.; Ottobelli, M.; Ionescu, A.C.; Paolone, G.; Gherlone, E.; Ferracane, J.L.; Brambilla, E. In vitro biofilm formation on resin-based composites after different finishing and polishing procedures. J. Dent. 2017, 67, 43-52. [CrossRef]

32. Polizzi, E.; Tetè, G.; Targa, C.; Salviato, B.; Ferrini, F.; Gastaldi, G. Evaluation of the effectiveness of the use of the diode laser in the reduction of the volume of the edematous gingival tissue after causal therapy. Int. J. Environ. Res. Public Health 2020, $17,6192$. [CrossRef]

33. Vallés, M.; Roig, M.; Duran-Sindreu, F.; Martínez, S.; Mercadé, M. Color stability of teeth restored with biodentine: A 6-month in vitro study. J. Endod. 2015, 41, 1157-1160. [CrossRef] [PubMed]

34. Ramos, J.C.; Palma, P.J.; Nascimento, R.; Caramelo, F.; Messias, A.; Vinagre, A.; Santos, J.M. 1-year in vitro evaluation of tooth discoloration induced by 2 calcium silicate-based cements. J. Endod. 2016, 42, 1403-1407. [CrossRef] [PubMed]

35. Schmalz, G.; Hiller, K.A.; Nunez, L.J.; Stoll, J.; Weis, K. Permeability characteristics of bovine and human dentin under different pretreatment conditions. J. Endod. 2001, 27, 23-30. [CrossRef] [PubMed] 
36. Tagami, J.; Tao, L.; Pashley, D.H.; Horner, J.A. The permeability of dentine from bovine incisors in vitro. Arch. Oral Biol. 1989, 34, 773-777. [CrossRef]

37. Kang, S.H.; Shin, Y.S.; Lee, H.S.; Kim, S.O.; Shin, Y.; Jung, I.Y.; Song, J.S. Color changes of teeth after treatment with various mineral trioxide aggregate-based materials: An ex vivo study. J. Endod. 2015, 41, 737-741. [CrossRef]

38. Lenherr, P.; Allgayer, N.; Weiger, R.; Filippi, A.; Attin, T.; Krastl, G. Tooth discoloration induced by endodontic materials: A laboratory study. Int. Endod. J. 2012, 45, 942-949. [CrossRef]

39. Jang, J.H.; Kang, M.; Ahn, S.; Kim, S.; Kim, W.; Kim, Y.; Kim, E. Tooth discoloration after the use of new pozzolan cement (Endocem) and mineral trioxide aggregate and the effects of internal bleaching. J. Endod. 2013, 39, 1598-1602. [CrossRef]

40. Ioannidis, K.; Mistakidis, I.; Beltes, P.; Karagiannis, V. Spectrophotometric analysis of coronal discolouration induced by grey and white MTA. Int. Endod. J. 2013, 46, 137-144. [CrossRef]

41. Shokouhinejad, N.; Nekoofar, M.H.; Pirmoazen, S.; Shamshiri, A.R.; Dummer, P.M. Evaluation and comparison of occurrence of tooth discoloration after the application of various calcium silicate-based cements: An ex vivo study. J. Endod. 2016, 42, 140-144. [CrossRef]

42. Aguiar, B.A.; Frota, L.M.A.; Taguatinga, D.T.; Vivan, R.R.; Camilleri, J.; Duarte, M.A.H.; de Vasconcelos, B.C. Influence of ultrasonic agitation on bond strength, marginal adaptation, and tooth discoloration provided by three coronary barrier endodontic materials. Clin. Oral Investig. 2019, 23, 4113-4122. [CrossRef]

43. Beatty, H.; Svec, T. Quantifying coronal tooth discoloration caused by Biodentine and EndoSequence Root Repair Material. J. Endod. 2015, 41, 2036-2039. [CrossRef]

44. Dettwiler, C.A.; Walter, M.; Zaugg, L.K.; Lenherr, P.; Weiger, R.; Krastl, G. In vitro assessment of the tooth staining potential of endodontic materials in a bovine tooth model. Dent. Traumatol. 2016, 32, 480-487. [CrossRef]

45. Kohli, M.R.; Yamaguchi, M.; Setzer, F.C.; Karabucak, B. Spectrophotometric analysis of coronal tooth discoloration induced by various bioceramic cements and other endodontic materials. J. Endod. 2015, 41, 1862-1866. [CrossRef]

46. Metlerska, J.; Dammaschke, T.; Lipski, M.; Fagogeni, I.; Machoy-Mokrzyńska, A.; Nowicka, A. Effect of citric acid on color changes of calcium silicate-based cements an in vitro study. Appl. Sci. 2021, 11, 2339. [CrossRef]

47. Camilleri, J.; Borg, J.; Damidot, D.; Salvadori, E.; Pilecki, P.; Zaslansky, P.; Darvell, B.W. Colour and chemical stability of bismuth oxide in dental materials with solutions used in routine clinical practice. PLoS ONE 2020, 15, e0240634. [CrossRef] [PubMed]

48. Vallés, M.; Mercadé, M.; Duran-Sindreu, F.; Bourdelande, J.L.; Roig, M. Color stability of white mineral trioxide aggregate. Clin. Oral Investig. 2013, 17, 1155-1159. [CrossRef]

49. Marciano, M.A.; Duarte, M.A.; Camilleri, J. Dental discoloration caused by bismuth oxide in MTA in the presence of sodium hypochlorite. Clin. Oral Investig. 2015, 19, 2201-2209. [CrossRef]

50. Berger, T.; Baratz, A.Z.; Gutmann, J.L. In vitro investigations into the etiology of mineral trioxide tooth staining. J. Conserv. Dent. 2014, 17, 526-530. [CrossRef]

51. Camilleri, J.; Montesin, F.E.; Papaioannou, S.; McDonald, F.; Pitt Ford, T.R. Biocompatibility of two commercial forms of mineral trioxide aggregate. Int. Endod. J. 2004, 37, 699-704. [CrossRef] [PubMed]

52. Palma, P.J.; Marques, J.A.; Santos, J.; Falacho, R.I.; Sequeira, D.; Diogo, P.; Caramelo, F.; Ramos, J.C.; Santos, J.M. Tooth discoloration after regenerative endodontic procedures with calcium silicate-based cements-An ex vivo study. Appl. Sci. 2020, 10, 5793. [CrossRef]

53. Felman, D.; Parashos, P. Coronal tooth discoloration and white mineral trioxide aggregate. J. Endod. 2013, 39, 484-487. [CrossRef] [PubMed]

54. Capparè, P.; Tetè, G.; Sberna, M.T.; Panina-Bordignon, P. The emerging role of stem cells in regenerative dentistry. Curr. Gene Ther. 2020, 20, 259-268. [CrossRef] [PubMed]

55. Fagogeni, I.; Falgowski, T.; Metlerska, J.; Lipski, M.; Górski, M.; Nowicka, A. Efficiency of teeth bleaching after regenerative endodontic treatment: A systematic review. J. Clin. Med. 2021, 10, 316. [CrossRef] [PubMed] 